\title{
Municipalities and regions in locational competition - Relevant factors for success and political implications
}

\author{
UDK: 352:323.174
}

\section{Thomas Döring}

Carinthia University of Applied Sciences, ISMA

t.doering@fh-kaernten.at

\section{Eithne Knappitsch}

Carinthia University of Applied Sciences, School of Management

e.knappitsch@fh-kaernten.at

\section{Birgit Aigner}

Carinthia University of Applied Sciences, School of Management

b.aigner@fh-kaernten.at

\begin{abstract}
Improving the business conditions of municipalities and regions, competitiveness concerning the location of new businesses and attraction of highly qualified labor are considered classical topics within regional economics and industrial location theory. Locational competition has intensified over recent years in the wake of the process of globalization, the general development towards a knowledge-based economy, and the dynamic of the international and the national division of labor. This analysis will be carried out in three steps. Firstly, traditional (e.g. industrial location theory) and newer economic approaches (e.g. new economic growth theory, innovative milieu approach etc.) will be outlined by means of discussing their insights and implications regarding the process of industrial location. This discussion shows that modern economies are increasingly developing into service and knowledge societies, in which factors formerly viewed as relevant within locational competition are becoming less important. Secondly, the paper analyzes the empirical evidence for these theoretical findings. According to existing empirical work, the evidence suggests that present studies mainly support the theoretically derived thesis of a shift in the classical ranking of locational factors. Finally, the paper seeks to explore conclusions concerning the design of local and regional economic policy at multiple governance levels.
\end{abstract}

Key words: local economic development, regional economic development, locational competition, hard location factors.

JEL: $H 7$ 
Döring, Knappitsch, Aigner

Municipalities and regions in locational competition -

Relevant factors for success and political implications

\section{Locational competition - current trends and relevant questions}

Progressing globalization and structural adjustment, accompanied by an intensification of the international division of labor as well as changes to the global sourcing of goods, materials, services, and finance, has plunged developed nations into an increasingly complex, uncertain and competitive world. Regions are forced to find their own place in the European and global division of labor (Keating 2001); while the notion of competitiveness has essentially become something of an omnipresent given in terms of economic development theory and policy. In addition, new technologies have set the world on the path towards becoming an information economy of knowledge-based industries, with specific requirements for new types of highly mobile, highly skilled and flexible labor and management (see Stimson et al. 2006; Läpple 2001). These fundamental changes lead to a situation where municipalities and regions face increased exposure (both domestically and internationally) to heightened competition in attracting production and service providing businesses, as well as a complementary labor force.

The increasing intensity of local and regional locational competition goes hand in hand with an increased mobility and flexibility of businesses and highly skilled labor, which in turn impacts the importance of local and regional factors of location. Economic studies based on company surveys in European countries arrive at the conclusion that more than $25 \%$ of the questioned businesses in Western Europe have made locationally relevant decisions: moving production to foreign countries in the two years prior to the survey. Austria is one of the countries with the highest business mobility rates: some $47.7 \%$ of all businesses having relocated production to foreign sites in the years 2007 and 2008 (see Kinkel et al. 2007; Breinbauer et al. 2008). This points to a significant location dynamic in modern industrial countries, especially when considering all locationally relevant processes. Included in these are - in addition to the business relocations and startups of new businesses typically considered in this context - also a multitude of "hidden" locationally relevant processes like, for example, the expansion or shrinkage of existing locations (relative to other locations), the founding and dissolving of local branches, or also the decisions of companies to remain at a certain location (provided they are confronted with the alternative of a possible relocation). 
Döring, Knappitsch, Aigner

Municipalities and regions in locational competition Relevant factors for success and political implications

Current economic tendencies, such as the internationalization of added value chains, the shortening of product cycles in the production and service sector, or the increasing importance of company internal real-estate management result in an even more significantly growing dynamic concerning the anticipation of future locationally relevant business decisions. As regards the locational competition of municipalities and regions, it is vital that the reasons for business-based location decisions are primarily of a local and regional nature and are thus location-dependent (see Blume 2006). This means that the specific advantages and disadvantages of the respective locations - in cities, municipalities, districts or regions - are, in the majority of cases, decisive for locational movement.

Against this background, an array of relevant questions concerning the appropriate behaviour of municipalities and regions in locational competition can be formulated. It is therefore interesting to consider how local and regional development processes in modern industrial countries must be constructed in order for municipalities to be able to maintain, and in future enhance, the position they have already attained. In the same right it is necessary to ask the question of which locational factors are currently important for the successful economic development of municipalities and regions and which will be important in the future. Finally, also of interest are the political recommendations that can be derived from newer theoretical analyses and empirical studies on the relevance of locational factors.

\section{Locational competition and locational factors from a theoretical perspective}

\subsection{The traditional view: Industrial location theory}

Traditional economic approaches to the analysis of locational competition have focused on the locational advantage or disadvantage in terms of the cost effectiveness of a locality or region. Explicitly spatial models of the processes by which firms choose where to locate their activities have been developed within (industrial) location theory. This theory addresses the question of why economic activities are unevenly distributed across space and also makes reference to the factors that firms consider in selecting a geographic location (see for classical texts on location theory Hoover 1948; Greenhunt 1956; Beckmann 1968; Smith 1971). Location theory has proposed that firms locate so as to 
Döring, Knappitsch, Aigner

Municipalities and regions in locational competition -

Relevant factors for success and political implications

minimize costs and seek locations that maximize their opportunities to reach markets; thus to maximize profits. Much of the emphasis has been put on transport costs, labor costs, other productions costs, scale of operation, and agglomeration economics (for a summary see Stimson et al. 2006; Edwards 2007).

The considerations embodied in location theory have contributed to the proposition that the sites in which businesses settled were deduced from spatially influenced production and distribution costs, which in turn influenced the prices of their products and ultimately their competitiveness. This explained to some extent the difference between urban and rural regions: strongly concentrated and lightly dispersed areas resulting from cost differences. In this context, the most important spatially relevant cost factors were considered to be acquisition and procurement costs, costs of distribution (marketing, selling, etc.) and costs of production. While procurement and distribution costs were deemed dependent on distance, production costs were seen as dependent on distance as well as on the degree of concentration of businesses (agglomeration benefits). The spatial distribution of economic activities can itself be subject to agglomeration effects because agglomeration benefits - mainly in the form of growing sales and procurement markets, which go hand in hand with cost reducing scale effects - can become greater with each increase in concentration. A lot of the work on agglomeration economies stems from the concept of the industrial district proposed by Alfred Marshall (1920), postulating that agglomerated factors constitute a theoretical link between the spatial structure of an economy and its growth dynamic (for an overview see Maier 2001; Feser 2001). Similarly, and in line with the traditional insights of location theory, so-called new economic geography indicates that agglomeration effects combined with transportation costs play an important role in local and regional development (see, for example, Krugman 1991; Ottaviano/Thisse 2003).

In view of the behaviour of a locality or region within a competitive setting, the implicit message of these traditional economic approaches is that municipalities and regional authorities can be successful when they offer a local environment for businesses that leads to a reduction of costs. Here, affordable access to raw material, quick accessibility to sales markets, low property prices or an agglomeration of businesses are considered conducive to lower costs. The focus of these approaches clearly lies on what are often referred to as hard locational factors like transportation infrastructure, local rate 
Döring, Knappitsch, Aigner

Municipalities and regions in locational competition Relevant factors for success and political implications

of taxes and duties, municipal real-estate management and office availability, locationally relevant production conditions, or even the extent of subsidies provided. Accordingly, the following political recommendations for a successful and competition-oriented organization of local and regional economic development can be deduced: Municipalities and regions can maintain or even improve on their position in terms of locational competition by binding businesses to their locations via low municipal taxes and duties, the provision of subsidies, investments in local transportation infrastructure, or through successful industrial real-estate management.

\subsection{New economic growth theory and modern regional economic approaches}

Classic location theory and the related political recommendations promising success for local and regional actors within locational competition has been called into question over recent years. On the one hand, mere experience has contributed to the conclusion that - contrary to what was postulated by location theory - the agglomeration of businesses in space and - connected to this local as well as regional economic growth were at their highest where the cost of living and office costs were high; industrial real-estate reserves were low; subsidies were either minimal or not offered at all; and the burden of local taxes and duties was comparatively high. This experience can be explained by the fact that modern economies are increasingly developing into service and knowledge economies, in which factors formerly considered relevant - like raw material or sales market orientation of businesses - are becoming less and less important (see various articles in Moldaschl/Stehr 2009 as well as in Cooke/Piccaluga 2006).

On the other hand, insights from new economic growth and modern regional economic approaches have led to a change in the economic assessment of locational competition and relevant locational factors. From a growth theory perspective, being adequately equipped and provided with (cheap) capital and labor is not considered decisive for the successful development of a locality or region, especially within industrial countries. A significant economic growth rate, one which is enduring and innovation-based, is attributed to the production factors "technology" and "knowledge" (in the latter case, for example, in the form of the accumulation of human capital). New growth theory models developed by theorists such as Romer (1987), Barro (1990), Rebelo (1991) 
Döring, Knappitsch, Aigner

Municipalities and regions in locational competition -

Relevant factors for success and political implications

Grossman and Helpman (1991) and Arthur (1994) allow for technological progress to be considered as an endogenous effect within the process of economic development. Furthermore, economists like Thomas (1975), Rees (1979) or Erickson (1994) have postulated that technology, innovation and knowledge are the primary drivers in local and regional economic development.

Against this background, the concept of innovative milieus was formulated in an effort to explain the emergence of a new technology generation: connecting the importance of agglomeration and localization economies, thus leading to the development of new industrial spaces (for more details see Scott 1988; Porter 1990 and 2000; Camagni 1991). In addition, some authors like Fukuyama (1995) and Blume and Sack (2008) have suggested that not only economic but also value and cultural factors (including social capital and trust) are important in the rise of knowledge based agglomerations. Furthermore collaboration among small and medium size enterprises through cooperative networks is believed to forge a powerful entrepreneurial business climate.

More specifically, these insights into a technology and knowledge based explanation of local economic development become the doctrine of agglomeration benefits through a regional economic reinterpretation. Agglomeration of businesses in space is first and foremost a factor that increases productivity. In contrast to what was emphasized in location theory, it is less the direct production and distribution costs that play a decisive role, but rather the positive scale effects brought about by "mutual learning" and "technology spillovers" (see among others Läpple 2001). Learning and innovation, the ability of businesses to create new products, new production procedures, and new forms of organization on the basis of knowledge and spatial knowledgespillovers, become critical success factors for local and regional economic development.

With respect to the locational competition of municipalities and regions, this leads to two conclusions. Firstly, cost leadership is no longer (solely) decisive in competition processes; the realization of a knowledge-based local and regional development is of increased importance and relies on an ability to cope with ubiquitous change by means of enhancing company innovativeness. This goes hand in hand with an important shift away from the "hard" locational factors, deemed rather static (transportation infrastructure, local taxes and duties, etc.), towards factors characterized as dynamic - for example the improvement of knowledge transfer between companies and institutions of 
Döring, Knappitsch, Aigner

Municipalities and regions in locational competition Relevant factors for success and political implications

higher education or research institutions of a region, the creation of innovative milieus and cooperative networks, as well as the accrual of highly qualified and creative personnel (see among others Camagni 1992; Fritsch et al. 1998; Stimson et al. 2006).

An ever greater role is now accorded to so-called "soft" locational factors, which is important among other things for the service capability of companies with knowledge-oriented jobs (see, for example, Logan/Swanstrom 1990; Smilor/Wakelin 1990). Soft "locational" factors are viewed as determinants for the quality of a locality and as such influence the decision of where businesses settle and where qualified and creative personnel decide to offer their services. Soft locational factors are on the one hand company-based factors like effectiveness and efficiency of the local administration, the image of a city and region, or the economic climate at that location. On the other hand, they include quality of life related factors like living environment, local and regional environmental quality, recreational value and allure of city and region as well as the quantity and quality of cultural activities and social institutions. From this perspective, new opportunities and also new challenges result. Thus the traditional political instruments used within the context of local and regional promotion of economic development lose their effectiveness under the altered conditions. At the same time, as a result of the increasing plurality of locational factors, there is also a rise in the number of competition parameters, which municipalities and regions use to present themselves as attractive for businesses and highly qualified labor in competition with other locations.

\section{Selected results from empirical research}

The previous considerations were largely of a theoretical nature and thus leave open the question of empirical evidence linked to the thesis of altered locational competition under the conditions of globalization and knowledge society and the related shift in the classical ranking of locational factors considered meaningful for the economic development of localities and regions. The following remarks aim to examine the interrelationship between empirical evidence and theoretical considerations. With this in mind studies addressing the relevance of knowledge, the spatial distribution of knowledge (knowledge-spillovers) as well as cooperative (innovation-oriented) networks for the economic development of municipalities 
Döring, Knappitsch, Aigner

Municipalities and regions in locational competition -

Relevant factors for success and political implications

and regions will initially be at the center of investigation. Subsequently, reference will also be made to those studies examining the empirical significance of soft locational factors in contrast to hard ones.

\subsection{The relevance of knowledge and knowledge spillovers}

The relevance of a knowledge-based local and regional development highlighted by new growth theory approaches and modern regional economics has led to an array of empirical studies in conjunction with knowledge, the spatial diffusion of knowledge (knowledge-spillovers) and economic development, as well as the innovation performance of businesses at individual locations (see among others Bode 1998; Griliches 1992). These studies have demonstrated that especially in metropolitan areas the geographical agglomeration of businesses that produce knowledge intensively contributes to positive economic growth rates and a higher per-capita value creation (see Kahnert 1998). These businesses are the ones that by means of innovative technologies create new markets as well as generate new value creation chains and employment opportunities. Here it has been found that the availability of highly qualified employees plays an essential role. It is, therefore, not surprising that the dynamic of economic development is empirically especially high at those locations considered among the classic technological locations, with universities and scientific research institutions in close proximity.

The finding that the economic use to which newly created knowledge is put and subsequently that the extent of so-called knowledge externalities are, as a rule, spatially restricted must be considered as of particular importance for local and regional economic policy (see Döring/Schnellenbach 2006). This is supported by empirical studies concerning the innovation performance of businesses in regions with major cities in the USA (see among others Audretsch/Mahmood 1994; Anselin et al. 1997; Varga 1998), by cross-country studies for selected regions in the European Union (see Botazzi/Peri 2003) as well as by studies for German labor market districts (see Niebuhr/Funke 2000; Franke 2002). For municipalities and regions alike this means that investments in a knowledge-based local and regional development appear to be profitable insofar as the possible profits of an economic promotion policy factoring in these elements primarily benefit the actors at the location.

In the context of a local economic policy such as that outlined above, empirical studies provide evidence of a positive correlation between how a region 
Döring, Knappitsch, Aigner

Municipalities and regions in locational competition Relevant factors for success and political implications

is equipped with universities and academic research institutions and the innovation activity of local businesses in knowledge-intensive producing branches. The study conducted by Jaffe (1989) can be mentioned here as exemplary. It traced a significantly positive correlation between academic research and the registration of patents as well as R\&D expenditures of companies in 29 US states. Empirical studies conducted afterwards confirm this finding for the USA (see, for example, Acs et al. 1999; Audretsch/Stephans 1996) as well as for Germany (see Edler/Schmoch 2001; Blume/ Fromm 2000; Frisch/Schwirten 1998).

Direct evidence of the importance of innovative milieus and cooperative networks, in connection with the production factor knowledge, for the positive economic development of municipalities and regions has been demonstrateed by Piore and Sabel (1984). Their study empirically identified the networking of local companies as playing a key role in the economic success of industrial clusters in Italy. An extensive number of studies on Italian industrial districts was later conducted and confirmed this finding (see Lazerson 1995; Gottardi 1996). Despite the fact that a multitude of institutional and organizational aspects of industrial clusters were examined, the factor "local and regional networking" was unanimously considered as central to the success characterizing all the industrial districts examined. A number of regional case studies concerning growth prominent industrial clusters in other countries have obtained the same result (see among others Saxenian 1994; Garnsey/Cannon-Brookes 1993; Maskell 1992). Irrespective of structural differences between the individual regions, the various studies suggest that when it comes to growth regions, regional networking is a key factor.

It can be concluded that networks of regionally clustered businesses and public institutions offer two broad opportunities: Firstly, formal exchanges of knowledge through market relationships, where proximity allows the establishment of closer ties; and secondly, the informal exchange of knowledge among social networks of individuals. A community's social life is considered to act as a knowledge multiplier, while the interconnection between social and economic networks within a community also contributes to a knowledge spillover (Falck and Heblich 2008). These considerations are consistent with empirical findings that cities better endowed with human capital have higher sustained growth rates (Glaeser et al. 1992). Municipalities or regions with skilled labor and high levels of specialized human capital are more likely to attract innovative networks compared with less endowed areas. This is confirmed by 
Döring, Knappitsch, Aigner

Municipalities and regions in locational competition -

Relevant factors for success and political implications

a survey of 84 businesses in the north-eastern USA which finds that the availability of skilled labor is the most important factor in influencing business site selection decisions (see Karakaya/Canel 1998). Empirical explorations of social capital data for German regions by Blume and Sack (2008) show evidence that regions with a high performance concerning social capital, which provided the necessary basis for regional networking and knowledge exchange, are characterized by comparatively higher income per capita values and economic growth rates.

\subsection{The importance of soft locational factors}

There has been little empirical testing of the theoretically developed thesis that soft locational factors have become increasingly important within the framework of a transition towards a service and knowledge-based society. One exception to this concerns the studies conducted by Florida (2005, 2002 and 2000), which were guided by the assumption that although in the age of globalization modern industries and businesses increasingly become geographically independent, questions of location take on greater importance in a new sense. Accordingly, growth and dynamic can be found where the highly qualified and creative establish themselves and where as a result complementary businesses settle ("the power of place"). Against this background, the question of which locational factors attract highly qualified top performers was examined in a survey involving data from 67 metropolitan regions in the USA.

Without claiming completeness or offering a systematic analysis, the results of the survey can be summarized as follows: The better the quality of life of individual locations, the greater the likelihood is of encountering industries with a large percentage of highly qualified employees. Locations with a well above average quality of life, which is expressed in a high living and recreational value, a positive social climate, an attractive inner city, a citizen-friendly administration, an adequate provision of social institutions, etc, provide for a distinct binding effect. Locations that do not exhibit any direct binding force upon enterprises or highly qualified employees, in contrast, do not carry the same attraction. These findings were confirmed in a study by Stolarick (2005) based on data from 61 urban regions in the USA, which examined the correlation between highly qualified employees and economic growth. Resultantly, those localities and regions competing for "creative minds" which increasingly emphasize the natural, social as well as cultural quality of life of a location and as a result focus more strongly on the implementation of soft locational factors 
Döring, Knappitsch, Aigner

Municipalities and regions in locational competition Relevant factors for success and political implications

proved to be especially successful. Looking at the question of culture specifically, one study carried out in Karlsruhe (Germany) analyzed the impact of cultural institutions on the competitiveness of enterprises located in this urban region. The study demonstrated that some $60 \%$ of the paticipating firms were of the opinion that cultural institutions have a favorable impact on the competitiveness of their economic activity (see Dziembowska-Kowalska and Funck 2000). It is perhaps of interest here that the region has included cultural activities in its urban development concept and regional growth promotion from the mid 1980s.

An empirical study carried out by Blume (2006) did not fundamentally challenge these findings, but relativized them in parts. By means of a survey of companies in 105 eastern German cities, Blume examined the influence of differently designed local economic policies on the local business climate as an indicator for the attractiveness of a municipality in locational competition. All municipalities exhibiting a positive business climate were found to have an efficient as well as speedy and flexible administration, modern governance structures (for example, new public management, city marketing, publicprivate partnership) and a well-functioning regional networking system (cooperation with Chambers of Commerce, regional academic research institutions, political decision-makers at regional and federal level, etc). By contrast, an intensive subsidization of businesses, comparatively high per-capita expenditures for cultural and social activities as well as shortfalls in the industrial real estate management of a municipality proved to have a negative influence on the local economic climate. Beyond this, there was evidence that neither the strategy of (extensive) privatization of public services nor a policy aimed to attract new businesses targeted at (existing) industrial clusters positively affect the business climate of municipalities.

Of further interest is a survey by Love/Crompton (1999) of 174 businesses in Colorado (USA). This survey aimed to identify the role of the quality of life in location decisions and asked key decision-makers to evaluate 50 specific elements regarding their level of importance within the decision process. On the one hand, the traditional factors "cost of office or plant", "business operating costs" and "access to transportation" reached the highest scores of 3.8, 3.7 and 3.6 on the 5-point-scale; but of relevance considering soft locational factors is the further distribution. Half of the 21 elements reaching scores above or equal to 3.0 related to soft locational factors such as "environmental quality", "Iocal government cooperation", "state government support/cooperation", "natural 
Döring, Knappitsch, Aigner

Municipalities and regions in locational competition -

Relevant factors for success and political implications

environment of the region", "crime rate" or "ambiance of the region" - to mention but a few.

The former findings suggest the conclusion that the success of municipalities or regions in locational competition does not depend per se on hard or soft locational factors. Rather, companies seem to ask for business conditions that are partly in keeping with the theoretically formulated necessity of a knowledge-based local and regional development (for example, the setting up of cooperative networks, citizen-friendly administrational departments) and at the same time utilize the instruments of a traditionally oriented economic promotion policy (infrastructure policy or industrial real estate management). Hard and soft location factors can then be considered as crucially intertwined, with dynamic regions typically characterized by the existence of several location factors.

\section{Conclusion - some economic policy implications}

Bearing the theoretical and empirical analyses above in mind, it is possible to derive conclusions regarding how best to structure economic policy for municipalities and regions. It is possible to distinguish between recommendations for an economic policy of municipalities and regions and those recommendations aimed at superordinate governmental levels (EU level, federal level) and their economic policy for municipalities and regions. For both dimensions, improving a knowledge-based local and regional economic development in order to increase the endogenous innovation of businesses both already locally based as well as those new companies yet to be attracted to the area is at the core of the following recommendations.

\subsection{Implications for a policy of municipalities and regions}

The starting point for a practical structuring of local and regional economic policy has previously been outlined: in the age of globalization and of a shift towards a knowledge-based society, the critical competitive advantage that companies must have when competing with others no longer only consists of cost advantages, but rather the ability to settle in those locations where there 
Döring, Knappitsch, Aigner

Municipalities and regions in locational competition Relevant factors for success and political implications

is a sufficient amount of qualified personnel. This is necessary in order to successfully manage innovation and the changes which are required to meet the demands of new economic challenges. With regard to competition between municipalities and regions, locations endued with a high potential for knowledge-based development on the one hand and locations displaying characteristics that are interesting for highly qualified and creative employees on the other hand, possess a competitive advantage in terms of their appeal for businesses and ability to bind them to the location.

As a consequence, it can be argued that conditions linked to a successfully structured local and regional economic policy are constituted by the promotion of knowledge transfer and the improvement of the local and regional qualifications structure. Without a doubt, all those municipalities and regions exhibiting spatial proximity to academic or educational institutions (mostly public or university-based), which on the basis of their research activities can be considered as knowledge providers for company-based innovation and can thus be classified as conducive to knowledge transfer, are at an advantage here. Hence, both the organizational and financial participation of a city or region in so-called knowledge transfer centers, which already exist at many universities and academic research institutions, as well as involvement in the promotion of new academic-based companies ("spin-offs") constitute a special form of knowledge transfer. For this, depending on the size and characteristics of a locations (metropolises, regions, middle-sized and small cities or municipalities), diverse strategies are needed to integrate individual municipalities into supra-regional networks based on their natural and socio-economic characteristics.

The sufficient availability of qualified labor at a particular location is one of the preconditions for the success of a knowledge-based local and regional development (see among others Franke 2002). Beyond mere faith in the "right" education and mobility performance of the private actors, a task of local and regional economic policy is the revealing, analysis and where possible the elimination of deficits in the local and regional qualifications structure. The education and training offered by further and advanced educational institutions available in a particular locality is also of importance here. In this context local and regional decision-makers should gear their policies for further education towards the existing locally relevant qualification demands via routine observations of the needs of the regional market (see Blume/Fromm 2000). 
Döring, Knappitsch, Aigner

Municipalities and regions in locational competition -

Relevant factors for success and political implications

A further condition necessary for a successful knowledge-based lo$\mathrm{cal} /$ regional economic policy is the promotion of local and regional innovation networks. Indeed the general character of regional networks and innovative milieu structures has already been repeatedly analyzed in economic studies (see, for example, Andersson/Persson 1993; Camagni 1993; Castells/Hall 1994; Fritsch 2002; Helsley/Strange 2002). However, the manifold of local and regional forms of such networks analyzed by these studies complicates rather than promotes their local use and predictability. A task of local/regional economic policy should thus be in creating a platform for the formation of innovative networks and milieu structures (see Smilor/Wakelin 1990). Experience would seem to indicate that a local or regional economic policy constructed as a "networking-policy" requires both patience and staying power and can hardly expect to anticipate success in the short term. Therefore, it makes sense to incorporate promotion of cooperative networks into a comprehensively constructed regional management strategy, which should also take into account locational marketing by public and private actors. This would outwardly convey the existing local and regional specialization pattern in a credible manner, which inwardly contributes to the creation of an intensified "location and regional awareness" with which the actors in a particular location can sufficiently identify. This sense of identification would ideally manifest itself in a common sense of belonging to a specific locality or region, thus sharing the aims and strategies of local marketing and regional management. This would in turn lead to a collective desire to enhance inner cooperation while at the same time improving the external competitiveness of a location.

Lastly, a further condition for a successful local/regional economic policy is seen in the use and awareness of soft locational factors in addition to a policy geared towards hard locational factors. This becomes increasingly significant as municipalities and regions in competition with each other can no longer generate enough competitive advantage simply through recourse to traditional instruments of economic promotion. A policy directed more strongly towards soft locational factors should be underpinned by a systematic examination of the existing necessity for the promotion of hard locational factors (i.e. investments in the physical infrastructure, availability and obtainment of industrial and office real estate) in order to subsequently free up necessary (financial) resources for the development and fostering of soft locational factors. As such, cities and towns should naturally concentrate on those soft factors which can most easily be shaped and designed at local and regional level (i.e. local administration, living environment, environmental quality). The fostering 
Döring, Knappitsch, Aigner

Municipalities and regions in locational competition Relevant factors for success and political implications

and enhancing of soft locational factors is less important in terms of economic externalities than it is for developing intensive business communication with enterprises already existing in the locality. Measures implemented to bring about improvements in this area should thus be evaluated first and foremost according to what extent they strengthen the competitiveness of the location; in order to encourage identification and mobilization effects for the local companies and employees.

\subsection{Consequences for a policy for municipalities and regions}

While in recent years regional development policy has tended to be more decentralized - either to regional or local level - where the ability to facilitate horizontal integration is highest and knowledge of problems is greatest, there is still some indication of the need to examine the policy for local and regional government operated by the superordinate authority levels. Clear signs of a reorientation in the regional and local promotion of economic development are found at European level. In its guidelines for European regional policy, the European Commission (2001) criticized the current concentration on measures promoting regional developmental shortcomings in areas like energy or transportation infrastructure as no longer being in keeping with the times. The Commission states in reference to the "transition to a knowledge-based economy" that an adequate, institutional framework must be created in order to promote the primarily regionally bound process of creating and diffusing new knowledge as the basis of company-based innovation and economic growth.

Against this background, the European Union has revised the aims of its regional policy for the new promotion period 2007-2013. Instead of the former nine program aims there are now only three aims at the center of promotion policy. Firstly, there is the convergence aim concerning financial promotion of those European regions that lag most in economic development. The strengthening of the competitiveness and employment potential of regions is also at the fore as the second aim. Thirdly, European regional policy continues to turn attention to the improvement of transnational and interregional cooperative relationships and networks (see European Commission 2007). However, even more notable than the reformulation of the promotion aims is the fact that just under two-thirds of the available financial resources are earmarked for those measures exhibiting a relationship to a knowledge-based local and regional development (see European Commission 2004). The four 


\section{Döring, Knappitsch, Aigner}

\section{Municipalities and regions in locational competition -}

Relevant factors for success and political implications

renewed pillars of the Lisbon Strategy are also significant in this context: a more attractive place to invest and work; knowledge and innovation for growth; creating more and better jobs; and a sustainable economic basis (see Heichlinger and Määttä 2006). The importance of local and regional actors as regards meeting these strategies is taken as a given.

Next to political measures at European level, there is also the question of a reorientation of economic policy at national level. Here, first of all, it is considered to be a matter of principle that governmental measures concerning the promotion of a knowledge-based local and regional development should be largely limited to supportive and stimulating tasks. Without discussing each measure in detail here, the general supposition is that the national political level should limit itself to providing an impulse in terms of the creation of an appropriate general framework for such developments. This can occur when national programs and financial appropriations provide incentives for local and regional actors to direct the attention of instruments of local and regional economic development to those measures which are of importance for a knowledge-based development strategy.

It must be said, however, that a national policy for municipalities and regions that accommodates the demands of the knowledge-based society should go hand in hand with a spatial concentration of appropriations. Thus a political interpretation of the new economic growth theory and modern regional economic approaches seems to lead to the conclusion that strengthening existing agglomeration benefits and the knowledge and innovation potentials connected with them, instead of working towards an equal distribution of such potentials in a spatial sense, is conducive to economy-wide growth. This is further supported by the fact that - according to the empirical findings - the intensity of the utilization of new knowledge especially in agglomeration and metropolitan areas is especially high. Accordingly, national appropriations concerning economic growth should be deployed where they generate the highest "return on investment" for the entire economy. Going against traditional economic approaches, the latter neither applies to knowledge-extensively producing old industrial regions nor to agglomeration-distant periphery areas. Instead of a regional equalization policy, preferential treatment is suggested for those regions and locations that can be classified as growth centers due to a spatial concentration of knowledge and knowledge-spillovers. 
Döring, Knappitsch, Aigner

Municipalities and regions in locational competition Relevant factors for success and political implications

\section{Thomas Döring}

Professor of Economics and Public Finance, Director of the Research Centre for Interregional Studies and International Management (ISMA), Carinthia University of Applied Sciences.

Eithne Knappitsch

Senior Lecturer and Scientific Researcher, Carinthia University of Applied Sciences, School of Management

Birgit Aigner

Scientific Researcher, Carinthia University of Applied Sciences, School of Management, 
Döring, Knappitsch, Aigner

Municipalities and regions in locational competition -

Relevant factors for success and political implications

\section{References}

- $\quad$ Acs, FitzRoy, and I. Smith (1999): High Technology Employment, Wages and University R\&D Spillovers: Evidence from US Cities. Economics of Innovation and New Technology, Vol. 8, pp. 57-78.

- Andersson and O. Persson (1993): Networking Scientists. Annals of Regional Science, Vol. 27, pp. 11-21.

- Anselin, Varga, and Z.J. Acs. (1997): Local Geographic Spillovers between University Research and High Technology Innovations. Journal of Urban Economics, Vol. 24, pp. $422-448$.

- Arthur, W. B. (1994): Increasing returns and path dependency in the economy. Ann Arbor.

- $\quad$ Audretsch, P., Stephan, E. (1996): Company-Scientist Locational Links: The Case of Biotechnology. American Economic Review, Vol. 86, pp. 641-652.

- Barro, R. J. (1990): Government spending in a simple model of endogenous growth Journal of Political Economy, Vol. 98, pp. 103-125.

- Beckmann, M. (1968): Location theory. New York.

- Blume, L. (2006): Local Economic Policies as Determinants of the Local Business Climate. Regional Studies, Vol. 40, pp. 312-333.

- Blume and D. Sack (2008): Patterns of Social Capital in West German Regions. European Urban and Regional Studies, Vol. 15, pp. 229-248.

- $\quad$ Blume and O. Fromm (2000): Wissenstransfers zwischen Universitäten und regionaler Wirtschaft: Eine empirische Untersuchung am Beispiel der Universität Gesamthochschule Kassel. Vierteljahreshefte zur Wirtschaftsforschung, Jg. 69, pp. 109-123.

- Bode, E. (1998): Lokale Wissensdiffusion und regionale Divergenz in Deutschland. Tübingen.

- Bottazzi and G. Peri (2003): Innovation and Spillovers in Regions: Evidence from European Patent Data. European Economic Review, Vol. 47, pp. 687-710.

- Breinbauer, Haslehner and T. Wala (2008): Internationale Produktionsverlagerungen österreichischer Industrieunternehmen. Ergebnisse einer empirischen Untersuchung. Wien.

- Camagni, R. 1993. Inter-firm industrial networks: the costs and benefits of cooperative behaviour. Journal of Industry Studies, Vol. 1, pp. 1-15.

- Camagni, R. (1991): Local ,milieu', uncertainty and innovation networks: towards a new dynamic theory of economic space. In: Camagni, R. (Hrsg.), Innovation Networks: Spatial Perspectives. London, pp. 121-144.

- $\quad$ Castells and P. Hall. (1994): Technopoles of the world: the making of the 21st century industrial complexes. London. 
Döring, Knappitsch, Aigner

Municipalities and regions in locational competition Relevant factors for success and political implications

- Cooke and A. Piccaluga (2006 ): Regional development in the knowledge economy. London.

- Dziembowska-Kowalska. and R. H. Funck (2000): Cultural Activities as a Location Factor in European Competition between the Regions: Concepts and some evidence. Annals of Regional Science, Vol. 34, pp. 1-12.

- Döring and J. Schnellenbach (2006): What Do We Know About Geographical Knowledge Spillovers and Regional Growth? - A Survey of the Literature. Regional Studies, Vol. 40, pp. 375-395.

- Edler and U. Schmoch (2001): Wissens- und Technologietransfer in öffentlichen Forschungseinrichtungen. ifo Schnelldienst, Nr. 4/2001, pp. 18-30.

- Edwards, E. (2007): Regional and Urban Economics and Economic Development: Theory and Methods. New York.

- Erickson, R. A. (1994): Technology, industrial restructuring and regional development. Growth and Change, Vol. 25, pp. 353-379.

- European Commission (2004): Proposal of 14 July for a Council Regulation laying down general provisions on the European Regional Development Fund, the European Social Fund and the Cahesion Fund, Brussel, COM (2004) 492 final.

- European Commission (2007): Cohesion policy 2007-13. Commentaries and official texts. Luxembourg.

- Feser, E. J. (2001): Agglomeration, enterprise size and productivity. In: Johansson, B. et al. (ed.), Theories of endogenous regional growth. Heidelberg et al., pp. 231-251.

- $\quad$ Falck and S. Heblich. (2008): Modern Location Factors in Dynamic Regions. European Planning Studies Vol.16 (10), pp.1385-1403.

- Florida, R. (2005): The flight of the Creative Class: The new global competition for talent. New York.

- Florida, R. (2002): The Rise of the Creative Class. New York.

- Florida, R. (2000): Competing in the Age of Talent: Quality of Place and the New Economy. Pittsburgh.

- Francois, J. (2001): Factor Mobility, Economic Integration, and the Location of Industry, Discussion Paper No. 0130. Centre for International Economic Studies. Adelaide.

- Franke, G. (2002): Regionale Wissens-Spillover und Innovationserfolge industrieller Unternehmen. Frankfurt am Main.

- Fritsch, M. (2002): Measuring the quality of regional innovation systems: a knowledge production function approach. International Regional Science Review, Vol. 25, pp. 86101.

- Fritsch, M. et al. (1998): Regionale Innovationspotentiale und innovative Netzwerke Zum Stand der Forschung. Raumforschung und Raumordnung, Jg. 55, pp. 243-252. 
Döring, Knappitsch, Aigner

Municipalities and regions in locational competition Relevant factors for success and political implications

- $\quad$ Fritsch and Ch. Schwirten (1998): Öffentliche Forschungseinrichtungen im regionalen Innovationssystem: Ergebnisse einer Untersuchung in drei deutschen Regionen. Raumforschung und Raumordnung, Jg. 56, pp. 253-263.

- Fukuyama, F. (1995): Trust: the social virtues and creation of prosperity. New York.

- Funke and A. Niebuhr (2000): Spatial R\&D Spillovers and Economic Growth - Evidence from West Germany. HWWA Discussion Paper Nr. 98. Hamburg.

- Garnsey and A. Cannon-Brookes. (1993): The ,Cambridge Phenomenonž Revisited: Aggregate Change Among Cambridge-High-Technology Companies Since 1985. Entrepreneurship \& Regional Development, Vol. 5, pp. 179-207.

- Gottardi, G. (1996): Technology Strategies, Innovation Without R\&D and the Creation of Knowledge Within Industrial Districts. Journal of Industry Studies, Vol. 3, pp. 119-134.

- Greenhunt, M. L. (1956): Plant location in theory and practice: the economics of space. Chapel Hill.

- Griliches, Z. (1992): The Search for R\&D Spillovers- Scandinavian Journal of Economics, Vol. 94, pp. 29-47.

- Grossman and E. Helpman (1991): Innovation and growth in the global economy. Cambridge (MA).

- Heichlingerand S. Määttä (2006): Good Governance in Delivering Sustainable Growth: Regions and Municipalities as Promoters of the Lisbon Strategy, Background paper for High Level Group and Meeting on Governance and the EU, Turku, 2-3 October 2006.

- Helsey and W. C. Strange. (2002): Innovation and input sharing. Journal of Urban Economics, Vol. 51, pp. 25-45.

- Hoover, E.M. (1948): The location of economic activity. New York.

- Jaffe, A.B. 1989. Real Effects of Academic Research. American Economic Review, Vol. 79, pp. 984-1001.

- Kahnert, R. (1998): Wirtschaftsentwicklung, Sub- und Desuburbanisierung. Informationen zur Raumentwicklung, Jg. 24, pp. 509-520.

- Karakaya and C. Canel. (1998): Underlying dimensions of business location decisions. Industrial Management \& Data Systems, Vol. 98, pp. 321-329.

- Keating, M. (2001): Rethinking the region: Culture, Institutions and Economic Development in Catalonia and Galicia. European Urban and Regional Studies, Vol. 8, No. 3/2001, pp. 217-234.

- Kinkel, Dachs, and B. Ebersberger (2007): Produktionsverlagerungen und Rückverlagerungen im europäischen Vergleich. Industrie Management, Jg. 23, pp. 47-51.

- Krugman, P. (1991): Geography and Trade. Cambridge (MA).

- Läpple, D. (2001): City and Region in an Age of Globalisation and Digitization. German Journal of Urban Studies, Vol. 40, No. 2/2001. 
Döring, Knappitsch, Aigner

Municipalities and regions in locational competition Relevant factors for success and political implications

- Lazerson, M. (1995): A new phoenix? - Modern putting-out in the Modena knitwear industry. Administrative Science Quarterly, Vol. 40, pp. 34-95.

- Logan. and T. Swanstrom (1990): Urban restructuring - a critical review. In: Logan and T. Swanstrom (ed.). Beyond the City Limits: Urban Policy and Economic Restructuring in Comparative Perspective. Philadelphia, pp. 3-24.

- $\quad$ Love and J. L Crompton (1999): The Role of Quality of Life in Business (Re)Location Decisions. Journal of Business Research, Vol. 44, pp. 211-222.

- Maier, G. (2001): History, spatial structure, and regional growth: lessons for policy making. In: Johansson, B. et al. (ed.). Theories of endogenous regional growth. Heidelberg et al., pp. 111-134.

- Marshall, A. (1920): Principles of Economics $8^{\text {th }}$ edition. London.

- Maskell, P. (1992): Learning in the Village Economy of Denmark: The Role of Institutions and Policy in Sustaining Competitivness. In: Braczyk, Cooke and M. Heidenreich (ed.). Regional Innovation Systems: The Role of Governance in a Globalized World. London, pp. 190-213.

- Moldaschl and N. Stehr (2009): Knowledge Economy. Marburg.

- Ottaviano and J.-F. Thisse (2003): Agglomeration and Economic Geography. CEPR Discussion Paper No. 3838. London.

- $\quad$ Piore and Ch.F. Sabel (1984): The Second Industrial Divide: Possibilities for Prosperity. New York.

- Porter, M. E. (1990): The Competitive Advantage of Nations. London.

- Porter, M. E. (2000): Location, Competition, and Economic Development: Local Clusters in a Global Economy. Economic Development Quarterly, Vol. 14, No. 1, pp. 15-34.

- Rebelo, S. (1991): Long run policy analysis and long run growth. Journal of Political Economy, Vol. 98, pp. 71-102.

- Rees, J. (1979): State technology programs and industry experience in the USA. Review of Urban and Regional Development Studies, Vol. 3, pp. 39-59.

- Romer, P. R. (1987): Growth based on increasing returns due to specialization. American Economic Review, Vol. 77, pp. 56-62.

- Saxenian, A.L. (1994): Regional Advantage, Culture and Competition in Silicon Valley and Route 128. Cambridge (MA) and London.

- Scott, A. J. (1988): New industrial space: flexible production organization and regional development in North America and Western Europe. London.

- Scott, A. J. (2004): Cultural-Product Industries and Urban Economic Development: Prospects for Growth and Market Contestation in Global Context. Urban Affairs Review, vol. 39 No. 4/2004, pp. 461-490.

- Smilor and M. Wakelin (1990): Smart infrastructure and economic development: the role of technology and global networks. In: Kosmetsky and R. W. Smilor (ed.). The technopolis phenomenon. Austin (TX), pp. 53-75. 
Döring, Knappitsch, Aigner

Municipalities and regions in locational competition -

Relevant factors for success and political implications

- $\quad$ Smith, D. M. (1971): Industrial Location: an economic geographical analysis. New York.

- $\quad$ Stimson, Stough, and B. H. Brian. 2006. Regional Economic Development. New York et al.

- Stolarick, K. (2005): The "Soft" Factors or Regional Growth: Technology, Talent and Tolerance. In: Thießen, F. et al. (ed.). Weiche Standortfaktoren - Erfolgsfaktoren regionaler Wirtschaftsentwicklung. Berlin, pp. 73-100.

- Thomas, M. D. (1975): Growth pole theory, technological change and regional economic growth. Papers of the Regional Science Association, Vol. 34, pp. 3-25.

- Varga, A. (1998): Local Academic Knowledge Spillovers and the Concentration of Economic Activity. Regional Research Institute, West Virginia University, Research Paper No. 9803. Morgantown 


\section{POVZETEK}

\section{OBČINE IN POKRAJINE V LOKALNI KONKURENCI - KLJUČNI DEJAVNIKI USPEHA IN POLITIČNE USMERITVE}

Članek obravnava teoretične vidike in rezultate empiričnih raziskav z vidika regionalnega razvoja. Upošteva tezo sprememb lokalne konkurence $\checkmark$ pogojih globalizacije in poslovanja, temelječega na znanju, ter posledičnega premika $v$ klasičnem rangiranju lokalnih dejavnikov, pomembnih za gospodarski razvoj mest in regij.

Analizo prikaže $v$ treh korakih. Najprej povzame klasične teorije (teorijo industrijske lokacije) in novejše ekonomske teorije (novo teorijo gospodarske rasti, pristop inovativnega okolja). Opiše njihove ugotovitve in priporočila glede industrijske lokacije. $S$ to razpravo potrjuje, da se sodobno gospodarstvo vse bolj razvija $v$ družbo storitev in znanja, $v$ kateri postajajo vse manj pomembni tako imenovani trdi dejavniki (npr. nizki stroški poslovanja, vrednost industrijskih nepremičnin, nizki lokalni davki in pristojbine). Za gospodarsko rast so vse bolj odločilni mehki dejavniki. Za lokalni in regionalni gospodarski razvoj so pomembni učenje in inovacija, zmožnost podjetij za oblikovanje novih izdelkov, novih postopkov proizvodnje in novih oblik organizacije na temelju znanja in mreženja ( prelivanja znanja). To je kakovost lokacije, ki zajema tudi kakovost življenja in okolja, in je odločilna v lokalni in regionalni konkurenci pri privabljanju investitorjev in delavcev s posebnimi znanji.

Nato članek analizira empirične dokaze za teoretične ugotovitve. Sedanji rezultati raziskav pretežno podpirajo tezo, da se ključni dejavniki lokalnega razvoja spreminjajo. Med najpomembnejšimi dejavniki uspeha so akumulacija znanja, prenos tega znanja med organizacijami, vrednost socialnega kapitala. Npr., empirična raziskava socialnega kapitala za pokrajine z visoko vrednostjo socialnega kapitala je pokazala sorazmerno višjo stopnjo dohodka na prebivalca in večjo gospodarsko rast.

Na temelju teh ugotovitev so predstavljena priporočila glede oblikovanja ekonomske politike občin in regij, pa tudi nacionalnih regionalnih politik in regionalne politike EU. 